\title{
LESSONS FROM HART
}

\author{
W. J. WALUCHOW
}

\section{Resumen:}

En este ensayo el autor defiende a H. L. A. Hart de dos críticas recurrentes a su teoría de las normas sociales y a las obligaciones que regularmente acompañan a estas normas. Ambas criticas, sostiene el autor, descansan sobre malos entendidos o caracterizaciones equivocadas de lo que Hart en realidad se propuso. Estos malentendidos son explicados plausiblemente a través de la falta de capacidad de los críticos de apreciar plenamente dos de las valiosas lecciones que Hart deseaba expresar en su lectura inaugural. En primer lugar, palabras como "norma" y "obligación" no deberian ser sacadas de sus distintos contextos de uso para someterlas a definiciones abstractas y al análisis filosófico. En segundo lugar, cuando se analizan enunciados en los cuales figuran tales palabras, tanto en la teoría como en la práctica del derecho, resulta primordial tener en mente las diversas funciones que esos enunciados puedan tener y los diferentes propósitos para los cuáles esos enunciados fueron proferidos.

\section{Palabras clave:}

Normas sociales, obligación, jurisprudencia analítica, filosofia del lenguaje, H. L. A. Hart.

\section{Abstract:}

In this paper, I defend H. L. A. Hart against two prevalent criticisms of his views on social rules and the obligations with which these rules are often associated. These criticisms, I argue, rely on misunderstandings or 


\section{W. J. WALUCHOW}

mischaracterizations of what Hart actually intended. These misunderstandings are plausibly explained by a failure on the part of his critics to appreciate fully two of the valuable lessons Hart sought to communicate in his inaugural lecture. First, words like 'rule' and 'obligation' should not be removed from their various contexts of use and subjected to abstract philosophical definition and analysis. Second, when analyzing assertions in which such words figure in both legal practice and theory, it is crucial to bear in mind the different functions these assertions can be made to serve and the different purposes to which they can be put.

\section{Keywords:}

Social Rules, Obligation, Analytical Jurisprudence, Philosophy of Language, H. L. A. Hart. 
Summary: I. Thoughts on Methodology. II. Rules and Social Practices. III. Rules of Obligation. IV. Are Social Rules Nothing but Social Practices? V. Himma, Hart and Austin: Still Apart after All These Years. VI. Concluding Thoughts.

\section{Thoughts on Methodology}

Upon assuming the Oxford Chair of Jurisprudence, H. L. A. Hart presented his inaugural lecture in which he warned of certain methodological traps into which legal philosophers sometimes fall. In issuing these cautions, Hart saw himself as following in the footsteps of his positivist predecessor, Jeremy Bentham, a philosopher Hart much admired, and from whom he thought we had much to learn. It is vital, Hart wrote, that we

...attend to Bentham's warning that we should not, as does the traditional method of definition, abstract words like 'right' and 'duty, 'State', or 'corporation' from the sentences in which alone their full function can be seen, and then demand of them so abstracted their genus and differentia. ${ }^{1}$

On the contrary, "we must never take these words alone but consider whole sentences in which they play their characteristic role. We must take not the word 'right but the sentence 'You have a right', not the word 'State', but the sentence "He is a member or an official of the State." 2 Furthermore, Hart suggested, we should always bear in mind that one and the same word or sentence, used in one context, can play a very different role, and mean something quite different, in another. "'Smith has a right to be paid £10' said by a judge in deciding a case has a different status

1 Hart, "Definition and Theory in Jurisprudence," in Essays in Jurisprudence and Philosophy (Oxford: OUP, 1983), 31.

2 Ibid., 26. 
from the utterance of it out of court, where it may be used to make a claim, or an admission and in may other ways."3

We can discern at least three different recommendations in these thoughts on methodology. First, in doing philosophy of law we should avoid the traditional, Aristotelian method of definition per genus and differentia. Second, no other method of definition, if applied to singular words like 'right', 'duty' 'corporation' or 'law' is likely to shed much light on the phenomena we seek to understand, at least in the case of a multi-faceted and somewhat puzzling phenomenon like law. Third, one and the same word or string of words can be used to serve different functions or roles in different sentences, as when a judge states that 'The defendant is liable for damages' and I later use this very same string of words in reporting that authoritative verdict. In other words, we very much need to be sensitive to the context of utterance when attempting to build an understanding of a phenomenon like law by examining the words and concepts typically employed in its analysis and/or practice.

There is no doubt much to dispute in these recommendations. ${ }^{4}$ But my aim in this paper is not to criticize Hart. Rather, I want to pick up on his important point that, in attempting to build a theory of law partly by looking at how its key terms and concepts are typically employed within its practice, it is absolutely crucial to bear in mind the varying contexts in which these terms and concepts can be used. More specifically, we should always ask whether the assertion in question is being made from what Hart famously termed the 'internal point of view' or from what he referred to as the 'external point of view.'

The importance of differing perspectives from which assertions can be made, so seemingly obvious, is one, unfor-

3 Ibid., 28.

4 See, e.g., Jonathan Cohen, "Definition and Theory in Jurisprudence" Proceedings of the Aristotelian Society, Supplementary Volumes, Vol. 29, Problems in Psychotherapy and Jurisprudence (1955), pp. 213-264. See also, P.M.S. Hacker, "Definition in Jurisprudence" The Philosophical Quarterly, Vol. 19, No. 77 (Oct., 1969), pp. 343-347. 
tunately, that legal scholars do not always seem to keep firmly in mind. And among the most egregious offenders are certain critics of Hart's views. Time and again one encounters positions ascribed to Hart that he could only have held had he, for some inexplicable reason, simply forgot his very own recommendations. It's as if Hart, in analyzing some of his key concepts, had ignored the importance of context of utterance and the attendant danger of attempting to understand words in isolation from the sentences in which they can be employed. Some of the most glaring examples are found in discussions of two notions central to Hartian legal thought - the notion of a social rule and that of the obligation with which such a rule is sometimes associated. My aim is this paper is to make some headway towards rectifying this situation. I want to help clear up some common misunderstandings of Hart's views on these two matters that are plausibly explained by failures fully to appreciate, as Hart himself almost always did, the importance of context and perspective when doing legal theory.

\section{Rules AND Social PRACTices}

In The Concept of Law, Hart presents himself as building a theory of law in response to perceived deficiencies in the views of his positivist predecessor John Austin. In Hart's view, one of Austin's most fundamental mistakes was his failure to provide the theoretical apparatus with which to explain what is commonly called 'the normativity of law.' As is well known, Austin attempted to reduce law to the empirically discernible commands of a sovereign who is habitually obeyed, and who has the power and intention to inflict sanctions should his commands be disobeyed. In effecting this reduction, Hart argued, Austin was unable to explain adequately the ways in which many people think about law and the normative vocabulary they employ when engaged in various activities either within, or in some way related to, legal practice. For example, those subject to law do not al- 
ways view themselves as simply obliged to obey its directives upon pain of penalty. They often view themselves as under its obligations and as possessing the rights and powers that law, via its secondary rules, creates and facilitates. With respect to those laws that impose obligations on them, they view themselves as bound by the relevant norms, not by any sanctions that might or might not be inflicted should they fail to comply. In order to capture and explain this normative dimension of law, its "internal aspect," we need, Hart claimed, to replace the notion of a command with that of a rule.

Yet if law is fundamentally a matter of rules, then a question naturally arises for Hart, as it does for any theorist who views law this way: Where do legal rules come from? Hart's answer was that many legal rules are brought into existence through the use of formal procedures like legislative enactment, a procedure made possible by a system's secondary, power-conferring rules. But this raises a further question: Where do these secondary rules come from and from where do they get their 'normative force'? According to Kelsen, we must presume a "basic norm" that authorizes the entire process, that gets it off the ground, so to speak. Wanting to anchor legality in social reality, Hart proposed instead that the relevant basic rules are neither presumed nor deliberately created via specified formal acts or procedures. Rather, they arise informally by way of the behaviour and attitudes - the practices - of those who willingly observe them and whose rules they are. Hart's famous rule of recognition is, of course, the foremost example of these special rules in virtue of which the normative, i.e. rule-governed practice of law comes into being. It is not postulated or presumed as in Kelsen's work. Nor is it formally enacted as in the case of the Canadian Criminal Code or the Canadian Charter of Rights. On the contrary, it exists within and as a result of the actual social practices of those whose rule it is. It is, in short, a "social rule." Such a rule exists when there is a pattern of behaviour accompanied by the appro- 
priate critical, reflective attitude. Members of the group who observe the rule not only engage in a fairly widespread and uniform pattern of behaviour, they also take an internal point of view toward that pattern:

What is necessary is that there should be a critical reflective attitude to certain patterns of behaviour as a common standard, and that this should display itself in criticism (including self-criticism), demands for conformity, and in acknowledgements that such criticisms and demand are justified, all of which find their characteristic expression in the normative terminology of "ought," "must," and "should," "right," and "wrong". 5

When these conditions are met, we can meaningfully say that the group engages in the practice of observing a social rule.

In his recent book, Legality, Scott Shapiro addresses this theory of social rules and accuses Hart of making 'a category mistake.'

Social rules cannot be reduced to social practices because rules and practices belong to different metaphysical categories. Rules are abstract objects. They are like games, numbers, plots, propositions, and concepts - they are objects of thought, not entities that exist within space and time...Practices, on the other hands, are concrete events. They take place within the natural world and causally interact with other physical events. ${ }^{6}$

Reducing rules to social practices — that is, claiming that a social rule just is nothing but a social practice- is a mistake, Shapiro believes. The mistake is revealed in a number of ways not least of which in "our way of talking about practices...We say that practices exemplify, embody, conform to, are structured by, and are grounds for rules. This

5 Hart, The Concept of Law, 2nd ed. (Oxford: Clarendon Press, 1994), 57.

6 Scott Shapiro, Legality (Cambridge: Harvard University Press, 2011), 103. 
strongly suggests that rules are standards that guide conduct, not the conduct itself."

Shapiro's charge that Hart has made a category mistake echoes criticism leveled years earlier by Ronald Dworkin in "The Model of Rules II." Here, Dworkin also claims that Hart's social rule theory mistakenly takes a social rule to be nothing but a social practice and views the assertion or expression of such a rule as nothing over and above a factual statement to the effect that the practice-conditions for the existence of the rule are satisfied. "The existence of a social rule, and therefore the existence of the duty, is simply a matter of fact." 8 Dworkin goes on to argue that people who invoke social rules in evaluating behaviour do not view them this way. This is certainly true of a person who finds the social practice "pointless, or silly, or insulting." Such a person "may believe that it does not even in principle justify asserting any duties or normative rules of conduct, and in that case he will say, not that it imposes a duty upon him which he rejects, but that, in spite of what others think, it imposes no duty at all." 10 It is true, Dworkin adds, that people who invoke rules often do assume a social practice such as Hart describes as an essential part of their justification for doing what they do. This might be, for example, because they do not wish to disturb settled expectations and cause the harm that might result from the frustration of those expectations. In such cases, "the social practice helps to justify a rule which [a] normative judgment states."11 But Hart's theory doesn't put things this way: it erroneously assumes that the rule just is the practice. In other words, Hart has committed the "category mistake" that Shapiro, years later, accused him of making. The existence of a so-

7 Ibid.

8 Ronald Dworkin, Taking Rights Seriously (Cambridge: Harvard University Press, 1978), 49-50.

9 Ibid., 58.

10 Ibid.

11 Ibid., 57. 
cial practice is an empirical matter of fact that can help justify the assertion of a normatively binding rule of behaviour and the normative judgments it supports. But such a practice can never itself be or constitute a normative rule.

\section{RulEs OF OBLIGATION}

Included within a society's social rules will be some that are thought to impose duties and obligations. ${ }^{12}$ These are the rules which the society's members generally view as vitally important to social life or some crucial part of it, and which they are willing as a result, and if necessary, to back up with serious social pressure. These rules are also characteristically recognized as requiring conduct that, while benefitting others, may come in conflict with self-interest. "Hence obligations and duties are thought of as characteristically involving sacrifice or renunciation."13 Rules prohibiting gratuitous infliction of harm and the keeping of promises typically count among a society's obligation rules; rules governing fashion and polite discourse usually do not.

Hart's theory of obligation has, like his theory of social rules, been subject to extensive critique over the years. ${ }^{14}$ Dworkin, for example, correctly pointed out that Hart was wrong to think that one cannot sensibly assert an obligation unless there is a social rule that supports its existence. Vegetarians, for example, can meaningfully claim that everyone has a moral obligation not to eat meat, despite the fact that doing so is an entrenched practice within virtually all societies. In the Postscript, Hart acknowledges the force of Dworkin's criticism, as well as the validity of Dworkin's

12 In most of his discussions of obligation and duty, Hart refers to the two interchangeably. I will follow Hart's lead here.

13 The Concept of Law, 87.

14 See, e.g., Richard Bernstein, "Professor Hart on Rules of Obligation" Mind, New Series, Vol. 73, No. 292 pp. 563-566; Roscoe E. Hill, "Legal Validity and Legal Obligation" The Yale Law Journal, Vol. 80, No. 1 (1970), pp. 47-75; Michael Green, "Legal Realism as Theory of Law", William and Mary Law Review, Vol. 46, No. 6 (2005), pp. 1915-2000. 
claim that he, Hart, had failed carefully enough to distinguish between the concurrent acceptance of a rule and the acceptance of a conventional rule. "A community displays a concurrent [acceptance] when its members are agreed in asserting the same, or much the same, normative rule, but they do not count the fact of that agreement as an essential part of their grounds for asserting that rule. It displays [acceptance of a conventional rule] when they do so."15 To this, Hart responds:

My account of social rules is, as Dworkin has also rightly claimed, applicable only to rules which are conventional... But the theory remains as a faithful account of conventional social rules which include, besides ordinary social customs (which may or may not be recognized as having legal force), certain important legal rules including the rule of recognition, which is in effect a form of judicial customary rule existing only if it is accepted and practiced in the law-identifying and law-applying operations of the court. ${ }^{16}$

Yet another criticism of Hart's theory of obligation is that it fails to mark a significant advance over Austin. ${ }^{17}$ According to this line of argument Hart, just like Austin before him, has presented a theory that reduces obligation to the threat of sanction, in Hart's case serious social pressure to conform. On Hart's view those subject to an obligatory social rule end up being obliged, not obligated, and so Hart himself falls prey to the devastating criticisms he launched against Austin's theory. In a recent paper, Kenneth Himma draws attention to this line of criticism and turns it on its head. Far from being a basis for rejecting Hart's theory of social obligation, this aspect of Hart's view actually reveals the great insight contained within it. The centrality of serious social pressure as an obliging force is actually a strong point in favour of Hart's theory of social obligations. Upon

15 Taking Rights Seriously, 53.

16 Ibid., 256.

17 So far as I know, Hart never did accept the validity of this criticism. 
making these points, Himma goes on to develop his own sophisticated and subtle theory of legal obligation that, as his title suggests, brings Austin and Hart together in ways few would have imagined.

Hart explains the binding character of social obligations in terms of considerations ordinary persons are likely to regard as having normative significance.... Social pressure in the form of a hostile reaction is something people with ordinary psychological characteristics tend to regard as having normative force...[I]t is an empirical fact that ordinary persons tend to dislike criticism and hostility and are willing to take at least minimal steps to avoid it...[I]t is clear that Hart views social pressure as being a necessary constituent of social obligation. As Hart puts the view, such pressure is the "primary characteristic of obligation." 18

So the binding force of social obligation is explained in terms of the characteristic desire of human beings to avoid social disapproval and pressure to conform. The "normative force" of an obligation rule consists in a kind of "sanction," just as it did in Austin.

\section{ARe Social Rules Nothing But Social Practices?}

At the outset I noted Hart's claim that context and point of view play important roles in legal theory. Words should not be yanked from their contexts of utterance and subjected to abstract definition; assertions should not be analyzed independently of the differing points of view from which they can be made. But this seems precisely to be what's going on in the critiques of Hart's theories to which I have just drawn attention -or at least this is what I will endeavour to show in the remainder of this paper. In so doing, I hope both to rescue Hart from the charge of egregious

18 Ken Himma, "Hart and Austin Together Again for the First Time: Coercive Enforcement and the Theory of Legal Obligation," presented at The Nature of Law, conference held at McMaster University, May 2011, p.p. 11-12. Internal reference to Hart is from The Concept of Law, 87. 
error and to lend support to the wisdom of heeding at least some of his inaugural lessons.

Let's begin with the charge, issued in effect by both Shapiro and Dworkin, that Hart has, in identifying rules with social practices, committed an elementary category mistake. What could possibly lead someone to make such a charge? The first thing to note is the way in which each theorist characterizes Hart's views. Here's how Shapiro puts it: "Hart tries to demystify the creation of social rules by reducing them to social practices. In other words, social practices generate rules because these rules are nothing but social practices....[S]ocial rules are just social practices." 19 With this definition in hand, Shapiro goes on easily to fashion an argument against Hart that reduces, essentially, to this: rules are abstract normative objects; social practices, on the other hand, are concrete events in the world; therefore rules cannot be social practices. Notice now how Dworkin describes Hart's theory:

Duties exist when social rules exist providing for such duties. Such social rules exist when the practice conditions for such rules are met. These practice conditions are met when the members of a community behave in a certain way; this behavior constitutes a social rule, and imposes a duty...The existence of a social rule, and therefore the existence of the duty, is simply a matter of fact. ${ }^{20}$

What could possibly lead one to take Hart as saying the sort of things attributed to him by Dworkin and Shapiro in these passages, as saying that a rule just is nothing but a social practice and that the "existence" of a social rule, and any obligation or duty to which it might give rise, is simply a matter of social fact? The short answer is that Hart undoubtedly thought that, in some (potentially misleading) sense and from one important perspective, these things can

19 Legality, 95, author's emphasis.

20 Taking Rights Seriously, 49-50. 
sensibly be said to be true. Let's focus, for the moment, on the claim that a social rule exists, leaving till later the claim that a social rule just is a social practice. When a sociologist or legal historian asserts the existence of a social rule within a particular society, his claim is true only if the social facts Hart describes obtain, only if there is in fact the converging behaviour coupled with the appropriate beliefs and attitudes that the existence of a social rule requires. From such an external, theoretical point of view, the existence of a social rule, accepted by its practitioners from the internal point of view, is determined by establishing the appropriate social facts, as is the existence of the duties with which it is associated. ${ }^{21}$

Let's now shift gears, however, and consider the social rule from the point of view of one who is subject to it, accepts its requirements, and invokes the rule in making normative assertions. ${ }^{22}$ When such a person asserts the existence of a duty under the social rule she might, of course, mean nothing more than what the legal historian means. This might be the case, for example, were she in the business of comparing the obligation rules practiced within her society with those practiced in another. But then again she might not. She might, in other words, assert that she actually does have an obligation to act in a particular way and cite the rule in defence of her claim and any actions she might take under its authority. But does she not thereby imply or presuppose her belief that the sheer existence of the rule within her society constitutes a sufficient reason

21 Notice how obscured this point becomes if we follow Shapiro's lead and, in effect, take Hart to have defined a rule simply as a social practice.

22 Hart is well aware that one who is subject to a rule's requirements might reject the rule, thereby assuming what Hart also calls, 'the external point of view.' One who thus rejects the rule and its requirements will dispute the normative claims of those who accept the rule. What he will not do, however, is dispute the claim of the historian. He rejects that he is subject to a valid normative requirement; not that there is a social rule which purports to impose one. For sake of simplicity, I will restrict my discussion to the differences between the historian and one who is subject to a rule and accepts it as establishing a valid normative requirement. 
for acting as she does? Would she, in justifying her behaviour by citing the rule that licenses or requires it, mean to assert nothing over and above what the historian asserts? Certainly not. As made plain in the Postscript, if the rule is a conventionally based social rule, then part of the reason behind her assertion will be the social facts Hart draws to our attention and to which the sociologist or historian will appeal in justifying his claim that the social rule exists. But it will almost certainly be only part of the reason. Another part might well consist in the various values, perhaps moral, perhaps not, realized in practicing the particular social rule in question. ${ }^{23}$ More importantly, whatever that additional element is, the fact remains that the claim being made by our rule supporter is not the same as the claim made by our legal historian; it is not, as Hart put it in his response to Dworkin, "a statement of the external sociological fact that the practice-conditions for the existence of the rule are satisfied." 24

So what kind of statement is it? The simple answer is that it's a normative statement, signalling the speaker's acceptance of the requirement that she behave as the social rule prescribes. One who wishes to dispute this particular statement will not necessarily (though she might) point to the absence of the practice-conditions historians could quibble over. She is more likely, however, to appeal to the absence of sound or valid reasons for doing as the social rule prescribes. She might, to use Dworkin's very own words, claim that the rule is "pointless, or silly, or insulting" 25 in which case her view will not be that there is a duty which she rejects but that there is no duty at all. And this

23 Hart claims that individuals can have any number of reasons for accepting and abiding by a social rule. See The Concept of Law, p. 257. This 'any reasons thesis' has been disputed by a number of theorists in regard to legal obligations. See, e.g., Raz, "Hart on Moral Rights and Legal Duties", Oxford Journal of Legal Studies, Vol. 4, No. 1, pp. 123-31, and Shapiro, Legality, p. 114.

24 The Concept of Law, 256.

25 Taking Rights Seriously, 58. 
will be because, in her view, the rule does not establish a valid normative requirement.

So from the internal point of view, the "existence" of a duty-imposing rule, i.e. one that actually does impose the obligation its practitioners take it to impose, is never merely a matter of sociological fact. But how can this be if, as Shapiro maintains, Hart has reduced social rules to social practices -claimed that a rule just is a social practice? If social rules are nothing over and above social practices, then if the requisite social practice exists, surely the duty exists. And this must be acknowledged from whatever point of view one cares to occupy. It is true that occasionally Hart comes perilously close to saying things that commit him to the reduction Shapiro attributes to him. For example, in his response to Dworkin Hart says this: "Rules are conventional social practices if the general conformity of a group to them is part of the reasons which its individual members have for acceptance...".26 Careful consideration of this claim does not, however, necessarily lend itself to the interpretation Shapiro would have us accept, that for Hart a social rule is reducible without remainder to a social practice.

Consider, once again, how Hart's claim, that rules are conventional social practices, looks depending on the perspective from which it is made. From the external point of view of an historian or legal sociologist, a social rule could, I suppose, loosely be said to be a conventional social practice in which general conformity is part of the reason its members cite for acceptance, criticism and so on. This is because such a theorist will be concerned neither with the question whether the rule really does provide the reason for action its adherents believe it to provide, nor with any metaphysical questions concerning the ontological status of rules. Rather, she will more likely be concerned with the empirical conditions under which rules can be said to exist within groups or societies. And given this concern there is no great harm in treating the rule as nothing over and

26 The Concept of Law, 255, my emphasis. 
above a social practice. But from the internal point of view, i.e. the point of view of one who actually cites the rule as part of her justification for what she does, the rule will never be sensibly viewed in this way. It will neither be constituted by nor reduced to the social practice in which she participates. Rather it will be what the social practice creates and establishes and helps to justify in the way of behaviour.

Yet if the rule is not identical with the social practice itself ( except in the very loose, and potentially misleading, sense associated with the legal historian or sociologist) then exactly what is it? To this Hart gives no clear answer of which I am aware. But there seems nothing in what he tells us that should lead us to think that he would reject the thought that the rule is, as Shapiro says, the abstract object expressed by or exhibited in the social practice the internal participant takes as providing part of her reason for behaving as she does. It is an abstract object created by and expressed in that social practice in much the same way that some other rule - perhaps the very rule in question under different circumstances - might be created and expressed by someone's writing a string of words on a piece of paper. As the old saying goes, there are many ways to skin a cat; there are also many ways to create and express one and the same rule. Writing is one of them; behaving in a particular way is another. It is perhaps worth stressing that none of this need be denied from the external point of view. When our legal historian or sociologist cites social practice as revealing the existence of a social rule, she need not be taken to have identified the rule with that practice. What she cites may be taken to constitute empirical evidence that a social rule exists, i.e. a rule having the distinctive character of having been created, and in that sense constituted by, the kind of social practice she describes. But the object created need not be viewed as identical with or reducible to the practice that expresses it and by which it comes into being - any more than a statutory rule need be viewed as identi- 
cal with or reducible to the acts of legislators or the strings of words that find their way into statute books.

\section{Himma, HaRt AND Austin: \\ Still Apart After All These Years}

Let's now turn to Hart's views on obligation rules. Himma suggests that we can arrive at the following insight from Hart's thoughts. The binding force of social obligation can be explained in terms of the characteristic desire of human beings to avoid social disapproval and pressure to conform. Thus, the "normative force" of an obligation rule consists in a kind of sanction, just as it did in Austin. To be clear, Himma does not maintain that the wish to avoid serious social pressure necessarily explains a person's motives in accepting a social rule under which he has an obligation, nor does he saddle Hart with this view. Social pressure is said to "explain how the rule...obligates, and not why [individuals subject to it] accept [the] rule." 27 In other words, we must, on this Hartian inspired theory of obligation, distinguish between reasons for accepting a rule, on the one hand, and the rule's "normative force," on the other. It's the pressure, not the reasons, that constitute the rule as obligatory and provide it with its so-called normative force.

I do not wish here to dispute either the soundness of this intriguing theory of social obligation or the account of legal obligation that Himma goes on to develop on its footing. Instead, I want to ask, as before, whether one can attribute such a view to Hart. And as before, I shall begin by looking at what actually Hart says, bearing in mind, once again, the importance of the point of view from which assertions concerning obligations can be made.

In presenting this thoughts on obligation, Hart cites three distinct, but related characteristics:

27 Himma, 17. 
1. "Rules are conceived and spoken of as imposing obligations when the general demand for conformity is insistent and the social pressure brought to bear upon those who deviate or threaten to deviate is great." 28

Two further characteristics of obligation are then said to "go naturally together with this primary one."

2. "The rules supported by this serious social pressure are thought important because they are believed to be necessary to the maintenance of social life or some highly prized feature of it." 29 ;

and finally

3. "[I]t is generally recognized that the conduct required by these rules may, while benefitting others, conflict with what the person who owes the duty may wish to do. Hence obligations and duties are thought of as characteristically involving sacrifice or renunciation...". ${ }^{30}$

Hart goes on to add this intriguing thought.

The figure of a bond binding the person obligated, which is buried in the word 'obligation', and the similar notion of a debt latent in the word 'duty' are explicable in terms of these three factors, which distinguish rules of obligation or duty from other rules. In this figure, which haunts much legal thought, the social pressure appears as a chain binding those who have obligations so that they are not free to do what they want. ${ }^{31}$

With these words of Hart in mind, let's now consider the following questions. (a) What, in Hart's view, is an obligation rule? And (b) Under which rules do obligations arise

\footnotetext{
28 The Concept of Law, 86.

29 Ibid., 87.

30 Ibid.

31 Ibid.
} 
within a community? Put this way, one might naturally answer these questions much as Himma indicates -and go on to conclude that Hart has not, in fact, taken a significant step beyond Austin. But one would come to these answers, I submit, only if one ignored the important lessons of Hart's inaugural lecture- that is, only if one yanked the words 'obligation' and 'obligation rule' out of context and portrayed Hart as providing a definition in answer to question (a); and only if one fashioned a Hartian answer to question (b) that for some reason ignored the differing contexts from which the question can be asked and answers to it provided. But of course Hart explicitly rejected the utility of definitions in legal theory, and so it would be unfair to view him, in the passages cited above, as answering a question such as (a), just as it would be unfair to take him as answering the question "What is a social rule?" by replying simply that it is a social practice of a particular kind. As for question (b), here the importance of context comes acutely to the fore because we get very different answers depending on the point of view from which the question is put.

Let's begin with the external, theoretical point of view of our legal historian or sociologist. On this reading, the question asks how, from the perspective of such an external observer of a society and its workings, one could distinguish social rules that function as obligation rules from those that do not. ${ }^{32}$ Hart's answer, of course, is that we would look to those rules that bear the features he mentions: they require personal sacrifice, are accompanied by serious social pressure and demands for conformity, and there is a widespread belief that these responses are appropriate because the rule protects what is taken to be a crucial feature of social life or some highly prized feature of it. Now consider these important points, so seemingly obvious, yet in need of emphasis: the question so framed calls for a

32 Notice how Hart phrases his analysis: "Rules are conceived and spoken of as imposing obligations when..."; These rules are "...thought important because they are believed to be necessary..." and so on (my emphasis). 
descriptive answer drawing on relevant social facts about behaviour and beliefs. And this is precisely what Hart provides. The "existence" of an obligation rule is, from this external perspective, a matter of sheer social fact. It's a matter of whether or not the right practice conditions obtain. It follows from this that, in citing the belief that the rule is valuable because of its role in contributing to the maintenance of social life or some valuable feature of it, the external theorist who follows Hart's lead in no way commits himself to the truth of the belief he reports. On the contrary, he might view the belief as blatantly false because he, unlike those who accept it, views the rule as "pointless, or silly, or insulting."

Now consider question (b) from the internal point of view, that is from the point of view of one who views the rule as actually providing him and others with sound or valid reasons for action. 33 Will such a person answer question (b) by citing the features Hart describes? Will he cite the serious social pressure to conform and the widespread belief that the rule promotes or protects important values? Of course he won't. He'll cite the important values. From his internal perspective, it's not the serious social pressure that produces the chain that binds, that provides the normative force that Himma seeks. Instead it's the values in light of which such pressure and criticism are believed to be warranted or justified. That the shared social rule is, in his estimation, actually necessary to social life, or some highly prized feature of it, is a good part of the reason why it counts among those rules that actually impose obligations on him. ${ }^{34}$ From his perspective, the "existence" of obligation

33 Bear in mind that, for reasons of simplicity, I have left out the so-called external perspective of one who is subject to the rules but rejects them, perhaps because he believes that the feature of social life protected - e.g., patriarchy - is in no way valuable.

34 Hart's "any- reasons-thesis" entails that the values invoked by those who consider themselves bound by the rule may differ from person to person. But for any such person, except perhaps one who acts from unthinking habit, or who is under the spell of unadulterated rule-fetishism, there will be some value or other to which appeal will be made. 
is not a matter of sheer social fact; it is not simply a matter of the right practice conditions being met. And finally, any attempt to define his obligation in terms of sheer social practice, to reduce it to a constellation of behaviour, attitudes and beliefs, is to commit a "category mistake."

\section{Concluding Thoughts}

In this paper, I defended H. L. A. Hart against two prevalent criticisms of his views on social rules and the obligations with which they can be associated. These criticisms, I argued, rely on misunderstandings or mischaracterizations of what Hart actually intended. These misunderstandings are plausibly accounted for by a failure on the part of his critics to appreciate fully two of the valuable lessons Hart sought to communicate in his inaugural lecture. Words like 'rule' and 'obligation' should not be removed from their various contexts of use and subjected to abstract philosophical definition and analysis. Such a methodology, Hart advised, only serves to obscure and confuse. Furthermore, when analyzing assertions in which such words figure in both legal practice and theory, it is crucial to bear in mind the different functions these assertions can be made to serve and the different purposes to which they can be put. An assertion that invokes a social rule, made from the external, theoretical point of view of a sociologist or legal historian, can bear a meaning that differs greatly from one made from a different point of view - most notably the point of view of one who views the rule invoked as providing him with reasons for action, perhaps of an obligatory nature. In drawing these points to the reader's attention, I hope to have made some small headway in re-affirming the thought that, from H.L.A Hart, we still have much to learn. ${ }^{35}$

35 Thanks to Otto Phillips, Fabio Shecaira, Imer Flores, Juan Vega, Ken Himma and Enrique Caceres for helpful comments on earlier drafts of this paper. 